\title{
EMERGING POWERS AND PEACE NEGOTIATIONS: THE EXPERIENCE OF BRAZIL IN THE NUCLEAR TALKS WITH IRAN ${ }^{1}$
}

\author{
Monica Ellen Seabra Hirst ${ }^{2}$
}

\section{Overture}

This article examines the performance of Brazil as contributor to peaceful solutions and the de-escalation of global and/or local tension. In recent years, assertive diplomacy combined with an inclusive political approach became the essential nutrients of Brazilian attempts to help transcend deadlock negotiations in international security. This text analyses this aspiration with focus on the 20 Io Brazil-Turkey initiative - known as the Teheran Declaration - which aimed to mediate the international crisis caused by the Iranian nuclear program. Both countries worked together to persuade Iran to accept a fuel swap deal, which could de-rail a new round of United Nations Security Council (UNSC) sanctions against Iran. The findings presented in this text have been nurtured by academic literature, official documentation and interviews with diplomats, international officials and experts.

The structure of this article comprises five sections. The first section offers a brief overview of the presence of emerging powers in global security and their efforts to promote change in a liberal-dominated international order. The second section addresses the contents of Brazilian involvement

I Field research involved interviews with high level officials from Brazil (ex-foreign minister Celso Amorim, Ambassador Maria Luisa Viotti, Ambassador Regina Dunlop, Ambassador Guilherme Patriota, Professor Marco Aurelio Garcia, Professor Paulo Sergio Pinheiro), Ambassador Claude Heller from Mexico; international experts Marc Finnaud and Tim Caughley.

$2 \mathrm{PhD}$ in Strategic Studies by the Postgraduate Program in International Strategic Studies / UFRGS (PPGEEI-UFRGS) (2OII) and Master in Political Science by the University Research Institute of Rio de Janeiro (I982) and bachelor in History by PUC-RJ ( I976). Since 2012 she is a full professor of the Department of Economics and Administration of the Universidad Nacional de Quilmes and teaches at the Master's Degree in International Studies at Torcuato di Tella University. E-mail: hirstmoni@gmail.com 
in global security during the years of the Workers Party (PT) government, with special attention to the Middle East peace processes. The third section focuses on the Teheran Declaration; the ambiguities of the Western powers two-track approach and the implications for Brazil of an autonomous pathway in the negotiations with Turkey and Iran. The following section addresses the contentions aroused by the Declaration of Teheran coupled with the growing politicization of foreign policy in Brazil. The concluding remarks contain an ex-post assessment of the Teheran Declaration, suggesting that in view of later developments in US domestic politics, its dismissal in 20 Io may have not been the most sage for world peace.

\section{Emerging powers pro-activism in global governance}

During the first decade and a half of the twenty-first century, a group of emerging powers assumed a proactive presence in multilateral contexts in the promotion of normative and procedural innovations. These states sought to expand their autonomy and recognition within the international system and simultaneously acted as a propulsion force in the transition towards a multipolar order (Hurrell, 2006, 2013; Cooper \& Flemes, 2013). Emerging powers early century pro-activism, mostly based on soft power attributes, aimed to influence multilateral agendas dealing with economic, political and security matters. In different occasions, these emerging powers represented a new source of pressure bringing in an alternative prism to influence norms and institutional settings (Aguirre, 20I3). This became a gradual, disordered and uneven development in world affairs.

The 2003-2013 decade represented the golden period for emerging powers presence in global governance. During these years, countries such as India, Brazil and South Africa became a renewed source of international views, and resources. While broadening and deepening the scope of their commitments in world affairs, they designed innovative inter-state coordination, with special mention to the BRICS and the IBSA groupings ${ }^{3}$. Emerging powers collaboration worked on niche diplomacy to deal with pressing realities in the developing world in name of a non-westernized approach. In Middle East politics, focus geared towards the Palestine-Israeli peace process, the stability and unity of Iraq, a diplomatic solution for the Iranian nuclear

\footnotetext{
3 BRICS is a coalition that reunites Brazil, Russia, India, China and South Africa for economic, financial and political cooperation. The group's institutionalization occurred in 2009 and South Africa joined the coalition in 20II. IBSA - India, Brazil and South Africa Dialogue Forum - was created in 2003 as a space for political coordination, sectoral cooperation and investment cooperation through the IBSA Fund.
} 
program, and non-intervention in the changing landscape of Arab regimes (Hirst, 20I5).

The chance to sit together at the UNSC in 20II, as non-permanent members, became an opportunity for the BRICS-IBSA cluster to share and reinforce the values and perspectives on world politics that translated into a Southern critical appraisal of the post-cold war liberal peace concepts and prescriptions ${ }^{4}$. They voiced against the flaws of United Nations (UN) bureaucratic rings in defense of improved coordination between Security Council (SC), the General Assembly (GA) and the executive boards of the UN agencies. Accordingly, the Peace Building Commission (PBC) needed better interaction with the SC.

Whereas Western powers sought to expand the UNSC prerogatives to add pressure by way of coercion and intervention, emerging powers expressed their concern with US-NATO-UN orchestrated military operations accompanied by recalcitrant political pressure (Ferdinand, 20I4; Hirst, 20I5). In this context, the usage of sanctions became a source of tension and pressure at the SC. While systematically contesting their use at the UNSC, emerging powers underscored their concern in the cases of Iran (20IO), Lybia (2OII) and Syria (2OII) during their temporary membership. The increased use of sanctions by the UN went hand in hand with the expansion of intervention prescriptions. Coercion became a medicine to treat "counterterrorism, prevent conflict, consolidate peace agreements, protect civilians, support democracy (or oppose non-constitutional changes of government) improve resource governance, and limit the proliferation of nuclear weapons" (Biersteker, Eckert \& Tourinho, 20I6, p.I2). Although enacted in the name of pro-democratic values, sanctions and military interventions became a source of concern for most part of the developing world, particularly for their costly impositions on civilian population (Richmond, 2009; Richmond \& Tadjbakhs, 20II). This concern was essential in the 2010 Brazil-Turkey attempt to promote a nuclear deal with Iran.

\section{Brazilian assertive diplomacy and peace brokerage in the Middle East}

During the years of the Lula da Silva and Dima Rousseff presidencies, Brazil enhanced its quest for increased global presence and initiative capacity

4 See 20II UNSC statements: for Brazil: http://www.un.int/brazil/SC_2oII.html; for India: http://www.un.int/india/security2oIr.htm; and for South Africa: <http://www. southafricanewyork.net/speeches_pmun/speeches.php?year=20II\&category=I>. 
in world affairs ((Hirst \& Lima, 2006,Dauvergne \& Farias, 20I2; Hirst, Lima $\&$ Pinheiro, 2010; Hurrell, 2008). The search for international acknowledgement and increased political incidence accompanied the idea that redistribution of power was an indispensable for an endurable multipolar system. The innovations pursued in the international realm relied upon the belief system of Brazilian foreign policy intertwined with recent domestic political changes. Principled diplomatic aspirations found inspiration in the ideas of foreign policy formulators back in the I960s5. In this context, a generation of like-minded practitioners became responsible for Brazil expanded presence in global economic-social and political-security arenas ${ }^{6}$. A cluster Brazilian civil servants and experts assumed top posts in multilateral organizations expressing worldviews that merged diplomatic beliefs with the ideals defended by the PT ${ }^{7}$. Brazilian assertiveness relied as well on state institutions, to start with the Foreign Ministry, commonly known as the Itamaraty, under the eager orientation from the Presidential Palace, and the involvement of specific ministries and government agencies.

Throughout Lula's government, center-right wing parties and sympathizers severely attacked foreign policy orientations and practices. Dividing views on regional and global preferences gave way to growing politicization, which involved political, academic and the media. While, opposing orientations on foreign policy were familiar in Brazil, they escalated to a new degree of confrontation. This process is part of a broad process of maturation, linked to persisting attempts of pushing forward autonomous-oriented foreign policies. Milani, Pinheiro and Lima (20I7) have suggested that this process in Brazilian foreign policy links to a graduation dilemma. Accordingly, "the different positions, and even contradictions, in foreign policy guidelines during the PT's years in power can be best understood as a consequence of what we have called the graduation dilemma" (Milani, Pinheiro \& Lima 20I7, p. 597).

During the years of the PT-led administration, Brazil sat at the UNSC as non-permanent member in 2003-2004 and again in 20I0-20II. In both periods, Brazil voiced its concerns with the prescriptions of liberal interna-

5 Araujo Castro and Santiago Dantas were the "founding fathers" of Brazilian Independent Foreign Policy enforced in the I960-64 period. See: Manzur, 20I4; Vizentini, I994.

6 The outstanding examples were: Roberto Azevêdo, as General Director of the World Trade organization( WTO); José Graziano da Silva, as General Director of the Food and Agriculture Organization of the United Nations (FAO); Paulo Sérgio Pinheiro, as Chairperson of the Independent International Commission of Inquiry (COI) on Syria; Paulo Nogueira Batista Jr., as executive vice president of the New Development Bank (NBD - the BRICS' bank); Bráulio Dias as Executive Secretary of the United Nations Convention on Biological Diversity (CBD); Sergio Duarte as United Nations High Representative for Disarmament Affairs (UNODA).

7 Interviews to Brazilian diplomats and experts. 
tionalism and questioned Western powers interventionist justifications (Richmond, 2009; Richmond \& Tadjbakhs, 20II). When addressing severe political unrest and the escalation of violence, Brazilian diplomats advocated for the promotion of capacity building and the strengthening of local authorities together with collective security solutions. The country also vindicated the improvement of the UN institutional-juridical frameworks and the importance of humanitarian international law (Uziel, 20I3; Hermann, 20II). Brazilian views expressed apprehension regarding the legitimacy of the use of force and coercion in international intervention, with special concern to the humanitarian impact of military action (Fonseca, 20II). Extreme poverty and the lack of institutional resources of countries subject to military intrusion were interpreted as consequences of colonial and neocolonial rule practiced by the same states that stood up for intervention. When addressing vulnerable countries, Brazilian diplomacy avoided using terms such as failed, fragile or weak states for their stigmatizing and prejudicial character (Hirst, 2015).

Commitment to peaceful resolution of conflict has been an essential premise and practice of Brazilian foreign policy (Guimarães \& Almeida, 20I7). Under the Lula administration, Itamaraty worked especially hard to expand the Brazilian role as a peace broker in global hurdling scenarios. Brazil's attempt to get involved and make a difference was a cumulative process and not the sum-up of audacious shots. For foreign minister Celso Amorim, this was

A calculated political, decision based upon specific evaluations of the course of possible action. Understanding other people problems had nothing to do with acting as a consensus entrepreneur. Contributing to peace processes did not part from normative prescriptions but from political reasoning; Brazil had the ability of putting itself in the place of others to help find acceptable solutions in deadlock international negotiations"

Accordingly, this could not be a solitary trail, nor could it rely on unilateral impulses. Soft power assets, teamwork with other emerging powers and pro-active multilateralism became core parts of the plot.

In this context, building bridges for Middle East peace became a strong aspiration of the Lula's government. Bilateral and multilateral activism were followed by meaningful gestures at the UN bodies, in a period when September II led Middle East matters in different UN bodies to become even more politicized $^{8}$. Parting from previous acquaintances with the Middle East

8 Brazil sought involvement in Middle East red spots before 9/II, with mention to Brazilian role in 1999 in the chairing three panels organized by the UNSC on Iraq. See: Springer, J. (I999). 
countries, Brasília sought to strengthen ties and create an atmosphere of trust and constructive connections with the Arab world based on high-level diplomacy (Messari, 2006; Silva \& Pilla, 20I2). An assorted agenda of projects filled-in an agenda of presidential visits, economic transactions, cultural exchanges, cooperation programs and close political understandings with Middle East governments. Brazil deepened affinities with the Arab countries by supporting old vindications and expressing disquiet about Western powers prejudices. Most of all, Brasília expected to become a peace contributor in the Palestine-Israeli contention. Brazilian presence at the Annapolis Conference in 2007- together with India and South Africa- and at the Conference in Support of the Palestinian Economy for the Reconstruction of Gaza, in Sharm ElSheikh in 2009, were perceived in Brasília as accomplishments in this direction ${ }^{9}$. In similar spirit, Brazil tried to mediate between Israel and Syria for the devolution of lost territory ${ }^{\mathrm{io}}$ and took part in the post-conflict Lebanese reconstruction ${ }^{\text {II }}$.

Brazil also intended to help find a peaceful outcome of the internal dismay in Syria initiated in 20II, taking advantage of previous political and economic good terms with Damascus (Pinheiro, 20I5). The country worked hard at the Security Council, together with the IBSA colleagues, to avoid the isolation of the Assad regime. Brazil had become growingly concerned with the Syrian crises and the damages caused by international intervention in Arab countries ${ }^{\mathrm{I2}}$ (Amar, 20I4). Involvement in the UN surveillance of the Syrian conflict unfolded into the Brazilian chairperson of the Independent International Commission of Inquiry (COI) on the Syrian Arab Republic, established in 2011 by the UN Human Rights Council' ${ }^{13}$.

Iran occupied an outstanding place on Lula's Middle East agenda. The

UN Panel on Iraq Recommends 'Reinforced' Monitoring Regime. Arms Control Association, from www.armscontrol.org/print/462.

9 In 2009, Brazil recognition of the Palestine State was followed by Argentina, Chile, Uruguay, Ecuador and Bolivia.

Io In 2004, Brazil switched its vote at the UNGA from abstention to a favorable in support to Syrian pledge to Israel for the recovery of the Golan Heights.

II In 2006, besides participation in humanitarian assistance efforts to attend Lebanese population, Brazil assumed the leadership of the naval component of UNIFIL, the UN peacekeeping mission in Lebanon.

I2 Author Interview.

I3 The COI on Syria has become the longest experience of an UN Independent International Commission of Inquiry in exercise given its actuation since 20II until present. From the very beginning, the COI on Syria - conducted by Paulo Sergio Pinheiro - became instrumental for the UN special envoy to help pursuing a political dialogue between all parts involved in the conflict. 
increase of trade, technological and scientific cooperation with this country reached unparalleled levels. Trade with Iran mounted from US\$ 500 million to US\$ I,24 billion in the 2002-2009 period and then to US\$2,I8 in $20 \mathrm{OI} 2^{\mathrm{I}}$. In 20I0, Iran was Brazil's second buyer for beef, after Russia ${ }^{15}$. Quickly the domestic and international repercussion of this rapprochement became a sensitive domestic and international front of PT foreign policy. Since the presidential victory of Islamic-nationalist Mahmoud Ahmadinejad, political radicalization in Iran became a source of irritation and concern for Western powers. Besides, the aggressive anti- Israeli stances defended by the Iranian leader contributed to deepen tensions in the Middle East, feeding international suspicion towards countries that shared positive agenda with Teheran. In this scenario, the Iranian determination to uphold autonomous nuclear-fuel capacity added even more steam.

The Lula da Silva and Dilma Rousseff foreign policy were strongly committed to longstanding nationalists premises, which included sovereign energetic resources and autonomous technology capacities (Vizentini,I998). The neo-developmental premises of the PT governments worked thoroughly to higher stakes in the nuclear global order (Kassenova, 20I4). Even though Brazil adhered to the Non-Proliferation Treaty (NPT), the country contested the nuclear international regime for its discriminatory approach imposed upon non-nuclear weapon states. Notwithstanding, Brazilian principled stances on the nuclear power did not translate into permissive views on non-peaceful programs in the developing world. Brasília was critical of India and Pakistan for their resistances to agree to nuclear disarmament, voiced its concern when North Korea decided to withdraw from the NTP in 2003 and defended international vigilance of the Iranian Nuclear Program (Patti, 20I0).

Brazilian political and normative stands on atomic power exceeded by far the importance of production and/or consumption of nuclear energy in the country ${ }^{16}$. Besides operating two nuclear power plants, with its own uranium enrichment capacity, and a third plant under construction, Brazil pursued the built-up of a submarine with nuclear propulsion. In truth, Brazil was "the first non-nuclear-weapon state to work on a nuclear-powered submarine" (Kassenova, 20I4, p. 2). The nuclear-powered submarine was part

I4 Data provided by the official statistics system of the Ministry of Industry, Foreign Trade and Services (AliceWeb), from http://aliceweb.mdic.gov.br//index/home.

I5 Associação Brasileira das Indústrias Exportadoras de Carnes (ABIEC). Exportações Brasileiras de Carne Bovina 20I0, from http://www.abiec.com.br/download/anual-2oıo.pdf.

I6 In 20I6, the nuclear power represented 2,6\% of the Internal Energy Supply in Brazil. See: Ministério de Minas e Energia (MME). (20I7). Resenha Energética Brasileira - Exercício de 2016. 
of Brazilian global aspirations; it represented an entrance door to the "select club of countries with nuclear submarines: the United States, Russia, France, Britain and China" ${ }^{\text {ז7 }}$.

Brazil sealed the non-military intentions of uranium enrichment capacities with the I988 National Constitution, then reinforced with the Nuclear Accord, signed with Argentina in I990 and the Adherence to the NTP in I99 $8^{\mathrm{I}}$. Brazilian commitment to nuclear non-proliferation has not implied the renouncement of fuel-enrichment capacity. Besides, Brazil preferred not to sign the International Atomic Energy Agency (IAEA) Additional Protocol on nuclear safeguards until nuclear powers complied with the disarmaments commitments $^{19}$. Nuclear powers perceive this preference as unsatisfactory if Brazil persists to continue with a dual-nature nuclear technology.

Brazil trajectory in nuclear non-proliferation was an essential pillar of its diplomatic assertiveness in the initiative with Turkey and Iran. For Brasília, defence of nuclear sovereignty and the search for a diplomatic solution to the Iranian tangle were two sides of a same coin.

\section{The Teheran Declaration}

In early 20I0, UNSC spotlight geared to Iran in face of its resistance to allow international inspection of its nuclear program, which led to the suspension of contacts with the Vienna Group ${ }^{20}$. Brazil and Turkey, as non-permanent members of the UNSC, proposed to Iran a diplomatic lane, perceived by both countries as acceptable to the Vienna Group and the International Atomic Energy Agency. Labelled as the Teheran Declaration, this initiative aimed to signalize that it was possible to re-establish talks with Iran to reach a sustainable nuclear deal. It parted from the assumption that Brazil and Turkey could help restore trust between Iran and the international community and avoid the approval by the UNSC of a robust package of sanctions against this

I7 Statement said by Dilma Rousseff at a naval shipyard's inauguration in Rio de Janeiro, in 20I3. See: "Brasil agora é parte do seleto grupo de países com submarino nuclear, diz Dilma Rousseff”. Poder Naval, March 4, 20I3, from http://www.naval.com.br/blog/2013/03/04/ brasil-agora-e-parte-do-seleto-grupo-de-paises-com-submarinonuclear-diz-dilma-rousseff/.

I8 Brazil is also a signatory of the Treaty for the Prohibition of Nuclear Weapons in Latin America (Tlatelolco Treaty), which came into force in 1968.

I9 Brazil is among a handful of countries with significant nuclear activities that have not signed and/or ratified the NPT Additional Protocol. The list includes Algeria, Argentina, Egypt, Syria, and Venezuela (Kassenova, 20I4).

20 The Vienna Group was a reduced configuration of the ${ }_{5} \mathrm{P}+\mathrm{I}$ (five permanent members at the Security Council plus Germany) to expedite contacts between the AIEA and the Iranian government. Its members were Russia, France and the United States. 
country (Parsi 20I3). Even more importantly, both countries expected an acceptable deal would discard the chance of a military intervention - already in the air - against Iran (Parsi, 20I0; Bâli, 20I3; Amorim, 20I5; Aguirre, 20IO).

A sequence of failed agreements between this country and the European Union (EU) added to the impact of the election of the new Iranian president in 2005. Ahmadinejad immediately made public his disregard to previously arrangements with the IAEA and contested the systematic approval by the UNSC of sanctions upon Iran ${ }^{21}$. International tension escalated in 2006 , after the IAEA disclosed the information on two unaccounted fuel-enrichment facilities in this country ${ }^{22}$. In 2009 , the Iranians refused a swap deal offered by the Vienna Group by which $75 \%$ of Iranian low enriched uranium (LEU) would be exchanged for fuel to supply the Teheran Reactor ${ }^{23}$. At this point, the IAEA declared there was no assurance of the non-military intentions of Iranian nuclear activities. Negotiations with Iranian officials had been completely derailed and the approval of a new round of UNSC sanctions became the most likely scenario.

Brazilian efforts to contribute to a peaceful resolution of the Iranian nuclear hurdle went through three different phases. The first phase initiates during the Brasília-Teheran exchanges in late 2008 to organize Ahmadinejad state visit to Brazil ${ }^{24}$. Besides bilateral talks on trade, Iranians were eager to find ways to by-pass US and EU sanctions ${ }^{25}$. At this point, Western powers suggested that Brazil could play a brokerage role in nuclear negotiations with Iran. President Obama's message welcoming friends that had "not chosen to turn their backs" on.

Iran became a strong incentive. Previous contacts with EU president Javier Solana and Al Baradei at the IAEA had been incentives in the same direction (Amorim, 20I5). The Obama administration expressed its intention to pursue a double-track approach, in which diplomacy counter-balanced

2I The AIEA monitored the Iranian Nuclear Program since 2003. See: https://www.iaea.org/ newscenter/focus/iran.

22 UNSC res.I696 (2006), res.I737 (2006), res.I747 (2007) and res.I803 (2008) demanded that Iran suspend fuelenrichment activities and imposed sanctions upon the country.

23 The AIEA monitored the Iranian Nuclear Program since 2003. See: https://www.iaea.org/ newscenter/focus/iran 23 Fuel would be enriched to $20 \%$ in Russia and sent to France for transformation into rods to fuel the Tehran Research Reactor.

24 Talks regarding the presidential visit to Brazil to take place in November 2009 initiated during Celso Amorim trip to Teheran, the first time in I7 years that a Brazilian Foreign Minister visited Iran.

25 Brazilian authorities made a distinction between multilateral sanctions, which they supported, and bilateral sanctions. These had important impact on areas of transaction as oil and energy. 
with coercion (Obama, 20I0). The US and EU were decisive for Brazilian government to step on board and define the scope of what could be achieved with Teheran: "The aim was to open a door which could lead to a broader understanding with the Iranians" ${ }^{26}$. This expectation coupled with a yet ephemeral idea that Brazil and the US could work together in international peace processes, in a broader sense. Negotiations, in this case, translated into recovering the acquiescence of Teheran to accept a swap deal, following the scheme previously conceived by the ${ }_{5}^{\mathrm{P}+\mathrm{I}}$. Shortly after, however, the change of tone in White House exchanges with Planalto Palace unsettled the idea of a US-Brazil-Turkey coordinated negotiation with Iran. In place, a growing apprehension regarding the implications of Ahmadinejad visit to Brazil took over bilateral conversations ${ }^{27}$.

A second phase starts with the Iranian presidential visit to Brazil in November 2009 and ends when the Teheran Declaration becomes the focus of Brazilian mediation efforts. In spite of US growing ambiguity regarding Brazil's contacts with Iran, other Western powers kept a positive stance, particularly France. Brazilian diplomats became confident as Iranian officials compromised to suspend enrichment activities for 60 days with the expectation that UNSC sanctions could be avoided. A sequence of events take place during this phase: i) Iran refused Brazil's attempt to re-open negotiations of the ${ }_{5} \mathrm{P}+\mathrm{I}$ swap deal proposal; ii) the IAEA governor board approved a resolution condemning the Iranian government for not informing fuelenrichment activities and suggesting a new round of sanctions should be endorsed by the $\mathrm{SC}$; iii) Brazil, as a member of the IAEA, abstained in the voting of this resolution; iv) Brazilian government decided to give continuity to mediation efforts to get Iran acceptance of a swap deal; v) the Iranian government decided to expand enrichment capacities of its nuclear program; vi) UNSC members initiated consultations to design a new set of sanctions on Iran; vii) president Lula's state visit to Iran was scheduled for May 2010.

The third stage evolves during the months when Brazil and Turkey negotiated with Iran a revised swap deal. This phase coincides with Brazilian 20I0-20II mandate as non-permanent member at the SC. Sitting at the SC as non-permanent members was essential for both countries to deepen diplomatic acquaintance and work together in a renewed deal with Teheran. For Turkey, pairing with Brazil was unprecedented; this country had never been of special interest to Ankara. The Turkish government had been pursuing a diplomatic solution to overcome the Iranian impasse before partnership with Brazil became an option (Ozkan, 20ı0; Hacipasalioglu, 20I4). In 2006,

26 Author interview with Celso Amorim.

27 Author interview with Celso Amorim. 
Teheran had already accepted the Turkey offer to play as facilitator in Iran's exchanges with Western powers to keep its fuel-enrichment nuclear program. For the Turkish government this could meet two interests; it would be helpful for the long awaited membership to the European Union and could contribute to a comprehensive understanding between Iran and the US (Bonab, 2009). While Turkey was a less experienced member than Brazil at the SC, from a geopolitical standpoint, this country had more to offer as a mediating force in the Middle East. Involvement with the Iranian nuclear hurdle was part of a broader foreign policy determination to influence regional peace processes, especially the Israel-Palestine dispute. Similar to Brazil, Turkish impulse linked to domestic political changes; the ascension of the Justice and Development Party's (AKP - Adele ve Kalkınma Partisi) in 2002 brought together the determination to expand influence in the region and to strengthen an autonomous posture. In 2003, Washington was caught by surprise when Turkey, in spite of being a NATO member, did not allow the US military to use its territory for logistic support during the Iraq War. Since 2009, as a non-permanent member at the SC, Ankara deepened its commitment to the Palestine cause, which led to growing tension with the US (Karajah, 20I2).

The Brazilian-Turkish agreement was to stay as close as possible to the original Vienna Group proposal, keeping in mind the conditions defined by the US president regarding the quantities and timing of the fuel swap, the transference to a third country and the formalities with the IAEA (Amorim, 20I5). As stated by Celso Amorim in interview for this work, "all through talks with Iran, following initial instructions from the US was crucial. Even though, finetuning an acceptable revised deal with Iran turned out an arduous negotiation with harsh exchanges". During the tripartite talks, Brazil and Turkey accepted the Iranians request that the rights to fuel-enrichment and non-discriminatory treatment be included in the Declaration draft.

The essence of the Teheran Declaration was a nuclear fuel swap deal in which Iranians would preserve their sovereignty - understood as the right to enriched uranium - and commit to non-military use of their nuclear facilities. The deal consisted in the acceptance by the Iranian government to deposit $\mathrm{I}, 200 \mathrm{~kg}$ of low enriched uranium (LEU) in Turkey monitored by Iran and the IAEA. Iran would deposit $1,200 \mathrm{~kg}$ of three to five percent enriched rods (that which represents nearly 50\% of Iranian stockpiled of LEU) in Turkey within a month of the agreement. In return, the Vienna Group (US, Russia, France + IAEA) compromised to deliver, within a year, twenty percent enriched fuel rods to Iran to be employed in its Research Reactor at Teheran. In case the swap did not occur, the declaration stated that Turkey would immediately return the LEU to Iran. 
Brazil and Turkey believed that winning confidence from ${ }_{5} \mathrm{P}+\mathrm{I}$ would hold back UNSC sanctions ${ }^{28}$. Notwithstanding, specialized media and scholars tend to share the view that this was out of question (Dreyfuss, 2010). Though the Teheran Declaration was initially a proposition induced by White House, the US had been sceptical all the way. The Obama administration never considered this initiative would be effective to prevent Iran from achieving the capacity to build a nuclear weapon. Hence, the US never made a sign that it would give up pursuing a new round of sanctions against Iran. While encouraging Turkey and Brazil to work on fuel swap deal with Iran, the US progressed negotiations with $\mathrm{P}_{5}$ partners at the $\mathrm{SC}$ to prepare a new and more severe set of sanctions on Iran. In fact, winning the support of Russia and China to approve the drafted resolution against Iran became more relevant for the US government than a successful Brazilian-Turkish negotiation. The increased enrichment capacity of the Iranian nuclear program expanded the uncertainty of its peaceful nature, that which became a compelling argument to justify coercive instruments as preferable to a diplomatic pathway.

In May 20I0, the Western powers responded deftly to the enthusiastic announcement of the Teheran Declaration made by the presidents Da Silva, Endorgan and Amadinejad ${ }^{29}$. The fact that Brazil and Turkey carried forward negotiations with Iran without a formal mandate justified the uncommitted reaction of world powers. The Teheran Declaration was questioned for it imprecision. It was considered outdated and unclear on specifics, such as the countries that would supply Iran with reactor fuel and the lapse of time when this would occur (Kassenova 20I4,p.90). In addition, the lack of endorsement made public by US authorities, particularly by Secretary of State Hilary Clinton, contributed to discredit the initiative and short live any positive impact that it could have ${ }^{30}$.

Brazil-US resentment became immediate and mutual. Brasília resented the sudden change of the Obama administration after explicit support; Washington complained that the Brazilian-Turkish negotiations with Iran could hurt the legitimacy of the SC resolution approving new sanctions for Iran.

28 Author interview with Celso Amorim.

29 See: LaFranchi, H. (2010). America’s New ‘Duel-Track’ Approach to Iran Nuclear Program. Christian Science Monitor, from http://www.csmonitor.com/USA/Foreign-Policy/2010/0520/ America-s-new-dual-track-approach-toIran-nuclear-program.

30 See: https://www.ft.com/content/58caa4b4-62a4-IIdf-bIdI-ooI44feab49a. 


\section{More odds than evens at the Security Council}

Even when successful, peace negotiations can fail for different reasons; one being the lack international acknowledgement. Brazilian and Turkish efforts to negotiate with the Iranians had become as intensive as the energy Washington spent to assure support at the CS for the approval of resolution I929, particularly from Beijing and Moscow. Chinese and Russian last moment switch resulted from concrete arrangements with the US and other Western powers that the sanctions would not hurt their relations with Iran. This left little time and hope for Brasília and Ankara to freeze the approval of the resolution at the SC. As negotiations at the SC concentrated on the inexorableness of a coercive solution, they completely dissociated from the search for a diplomatic solution with Iran. The fact that consultations and fine-tuning of the Resolution I929 occurred while Brazil-Turkey-Iran diplomatic talks were taking place narrowed the consensus building at the SC to a one-andonly track. When the Teheran Declaration was announced (May I7, 20IO), US pressure steamed at the SC for the approval of the I929 resolution. As the US held back any sort of applause to the trilateral deal, it became particularly difficult Brazil and Turkey mediation be granted international acknowledgement. Furthermore, effectiveness of the Teheran Declaration rapidly eroded when the Vienna Group casted doubts on its contents and the Iranian government delayed indispensable formalities with the IAEA. Resolution I929, approved on June 9, 20I0, imposed a complete arms' embargo on Iran, banned this country from all activities related to ballistic missiles, froze all assets pertaining to the Iranian Revolutionary Guard and Iranian shipping companies and imposed inspections of any Iranian cargo or financial institutions ${ }^{31}$. Hence, the SC approved sanctions were to transform the Teheran Declaration into a piece of waste.

The negative votes of Brazil and Turkey at the Council, though technically were no impediment for the approval of the resolution, did muddle the court for Western powers. Even though it had not been possible to hold back the Teheran Declaration, the US government did try to soften Brazil and Turkey to avoid a fragmented voting at the SC (Amorim, 20I5). Both countries coincided in the justification of their nays, though augmented differently in defense of mediation efforts. Turkey underlined the regional implications of the initiative and the responsibilities Iran should assume in the Middle East peace process. Brazil emphasized its disagreement with the use of coercive methods and criticized the secrecy of their negotiations, lamenting the out-

3I See: UNSC Resolution I929 (20I0), from www.un.org/en/ga/search/view_doc. asp? symbol=S/RES/1929(2010). 
comes of the approved resolution for Iranians and the world peace. The Lula's government took the decision to stand against the resolution two weeks before its voting, even though certain Brazilian and foreign diplomatic circles considered abstention a preferable option (Amorim, 2015). The decision to vote against resolution I929 assumed controversial connotations for Brazil's foreign policy. This was first time Brazil stood against a resolution at the SC, in 20 years of intermittent membership.

An overview of the statements at the SC shows that reactions to the Teheran Declaration were diverse and varied in tone ${ }^{32}$. Justification of sanctions coupled with the underscoring of the dual-track strategy. This had implied the acceptance of coercion and negotiation as complementary courses of action to safeguard the non-proliferation regime defied by Iran. Western powers shared similar standpoints, in which accusatory allegations against Iran justified a robust agenda of sanctions and lamented the shortcomings of the Teheran Declaration. The US representative (dis)qualified the initiative as merely an attempt to better the 2009 Teheran Research Reactor proposal. The French and British argued that the Teheran Declaration had not reached its purpose since it in fact allowed the Iranian government to maintain fuel enrichment activities. Developing countries siting at the SC - Gabon, Nigeria, Uganda and Lebanon - expressed positive views on the significance of confidence-building initiatives as the Teheran Declaration. Lebanon, the only country to abstain, showed utmost concern with the difficulties faced by the Middle East to become a zone free of nuclear weapons, particularly the refusal of Israel to adhere to the NPT.

It is worth noting that Mexico - the other Latin America temporary member at the $\mathrm{SC}$-, who presided the Council at the time, while overemphasizing commitment to non-proliferation, completely ignored the Teheran Declaration. Two explanations help understand this omission: the systematic lack of convergence between Mexico and Brazil on matters of global governance, with mention to their differences regarding the proposals for the reform of the Security Council; secondly, Mexico-US close ties in issues of world peace and security. Mexico's argued that Brazil had not shared information on the negotiations with Turkey and Iran and that the Teheran Declaration had been a "general surprise" (Heller, 20I2, p. 27). Besides, Mexico did not consider this a pertinent initiative, interpreted as a Brazilian mediatic gesture and a source of enormous irritation for Western powers ${ }^{33}$.

32 See the documents related to the 6335th UNSC meeting, on 9 June 20I0, when the Resolution 1929 was adopted, from http://repository.un.org/handle/III76/I4002 33 Author interview with Claude Heller.

33 Author interview with Claude Heller. 


\section{Domestic politicization and beyond}

In Brazil, the Teheran Declaration became an immediate matter of politicization. The Foreign Ministry advocated that negotiations with Iran "could help avoid a worst case scenario" 34 . According to Minister Amorim, Brazil would as well achieve a new status in international brokerage for peace. Following the orientation of the autonomous school of thought, Amorim found inspiration in former foreign minister Santiago Dantas words: "If you help solving problems, you become more prestigious and are allowed to grow without giving away principles"35.

The coming and going of Brazilian and Turkish diplomats to Teheran, spotlight by local and international media, was at once a source of politicization in Brazil. In attendance to an open session of the Foreign Affairs and National Defense Committee of the Brazilian Senate, Amorim tried to win support for the Teheran Declaration. He alerted at the implications of the hurried US-led sanctions approved at the $\mathrm{SC}^{36}$. Yet the strident lack of domestic support manifested before, during and after the Teheran Declaration prevailed. Brazilian conservative circles questioned Itamaraty autonomous stances; they gave little credit to mediating efforts and supported a new round of UNSC sanction against Iran. Three allegations stood out: i) negotiation efforts with Iran compromised the international credibility of Brazilian nuclear program ${ }^{37}$; ii) This initiative illustrated a dangerous and undesirable relationship between Brazil and Iran ${ }^{38}$; iii) Brazil held no stakes in the Middle East to justify such involvement.

The first point questioned the unnecessary costs of misunderstanding with the US and Western powers caused by the initiative and subsequent negative vote at the SC. It underscored the contamination effect this could have in non-proliferation matters. All existing arguments proper to legitimize the weight of Brazil in playing a constructive part in nuclear global politics twisted around to underscore its vulnerability and lack of authority. This point

34 Author Interview with Celso Amorim.

35 Author Interview with Celso Amorim.

36 See: Câmara Notícias (June 9, 20I0). Declaração de Teerã fez ONU apressar sanções ao Irã, diz Amorim, from http://www2.camara.leg.br/camaranoticias/noticias/RELACOESEXTERIORES/I48685-DECLARACAO-DE-TEERA-FEZ- ONU-APRESSAR-SANCOES-AOIRA,-DIZ-AMORIM.html.

37 See: Goldenberg, J. (March I5, 20I0). O Brasil, o Irã e as armas nucleares. O Estado de S. Paulo.

38 See: Lafer, C. (April I7, 2oıo). O Brasil e a nuclearização do Irã. O Estado de S. Paulo, from http://opiniao.estadao.com.br/noticias/geral,o-brasil-e-a-nuclearizacao-do-ira, 539754. 
related to the role of Brazil in global governance and the implications of foreign policy preferences on disputed agendas. This was a perfect illustration of how the long-standing dualities of Brazilian foreign policy, in which autonomous-oriented course of action opposed acquiescence to Western powers interests and rules (Milani, Pinheiro \& Lima, 20I7).

The second polemic alluded to the question of "good and bad company" in world politics. Once trilateral negotiations moved ahead, in spite of US twisted nose, they entered a sensitive terrain. Brazil and Turkey became more compelled to pursue trustful talks with Iran through bilateral channels, that which involved a strong dose of presidential diplomacy. Domestic press underlined that trilateral talks progressed thanks to the chemistry between presidents Lula and Ahmadinejad, with implications that went beyond the Teheran Declaration. Following such arguments, joint talks with Turkey were part of the decision to align with the Iranian regime in Middle East, which involved consent to its human rights violations ${ }^{39}$. This interpretation questioned the impartiality of tripartite negotiations, suggesting the government foreign policy decisions were biased and evil for the country.

A third line of reasoning touched the geopolitical dimension, bringing-in two corollaries; Geographic distance coupled and the inexistent religious clashes in Brazilian society. Why get involved in Middle East conflictive agendas? Besides, Brazil ought primarily to assume leadership and political responsibilities in the regional context, giving a hand to unravel long lasting inter-state boundary disputes and domestic political conflicts ${ }^{\circ}$. This allegation brought-up the fragile link between the regional and global dimensions of Lula's foreign policy and the costs of Latin American missing support to Brazilian global aspirations (Malamud, 20II). Notwithstanding the top priority of regional politics (particularly in South America) in Brazilian foreign policy during the years of PT government, its link with global aspirations was bumpy and uneven (Hirst \& Lima, 20I5; Vigevani \& Cepaluni, 2009). The poor results of Brazil project to build an inter-regional agenda between the Arab world and South America was an example of the lack of automatism in the regional-global nexus. Brazil acted as a regional power but did not count on regional support for its projection in global governance. The critical view

39 See: Lafer, C. (April I7, 20Io). O Brasil e a nuclearização do Irã. O Estado de S. Paulo, from http://opiniao.estadao.com.br/noticias/geral,o-brasil-e-a-nuclearizacao-do-ira,539754.

40 Besides Colombia, as mentioned, other "omissions" interviews to the author have been raised as the ArgentinaUruguay conflict on the paper mills, the Chile-Bolivia territorial dispute and the political crisis in Venezuela. See: O Estado de São Paulo (July 27, 2010). Entre o Erro e a omissão, from http://opiniao.Estadao.com.br/noticias/geral,entre-o-erro-ea-omissao-imp-, 586454 . 
to the Teheran Declaration on the part of Mexico, the other Latin American member at the SC in 20I0, was a telling sign of the lacking regional support to Brazil global aspirations.

Even when acknowledged for Brazil international projection, the media hardly gave credit to the diplomatic efforts per se or to its eventual contribution to the peace process in the Middle East. In fact, when the SC approved resolution I920, foreign policy condemnation became far more vociferous than the laments this setback could represent for world peace. Following a similar perspective, academics in Brazil and abroad, have questioned the Teheran Declaration for being ambitious and/or inconsistent with domestic and international restraints (Mares \& Trinkunas, 2016; Burges, 2013; Lafer, 2010; Ricupero, 20I0; Abdenur, 20I0).

In the years to come, the Teheran Declaration was a permanent issue in the polarization of Brazilian public debate on foreign policy. Domestic controversies on policy preferences escalated during the years of Dilma Rousseff presidency. The Rousseff government tried to keep a distance from the Iranian regime with a critical position to its human rights violations. Yet, political polarization led to ideological simplifications in which the nuances of the PT foreign policy became irrelevant. The crisis that caused the political and economic breakdown of Brazil in 2015 deepened even more the dismantlement of the countries' foreign policy pulse (Hirst \& Lima, 20I5). Brazilian presence curtailed and mediocritized in global and regional arenas (Rodrigues, 20I7). Ironically, after the coup against Dilma Roussef in 20I6, judgements regarding the foreign Policy of the Lula government have softened. In this context, the perception of the Teheran Declaration as a valuable source of diplomatic prestige is no longer shared exclusively by PT supporters (Ricupero, 20I7).

\section{Final (re)considerations}

The Teheran Declaration ought to be understood as a peace-seeking diplomatic initiative that intended to open path - at the time completely obstructed - to a more comprehensive negotiation. The reaction among nuclear power analysts to this initiative has been more favorable than that shared in international/national diplomatic circles and media. It links the initiative to the significance of emerging powers involvement in sensitive security matters. Qualified opinion state that as an emerging power, Brazil had the capacity of creating a "productive environment which helped break the ice and draw Iran to a constructive option", even more when Iranians could have been on 
the way to military use of their nuclear program ${ }^{4}$. Following similar lines: "non-Brazilian nuclear policy analysts stressed the importance of having alternative actors seek outcomes that are difficult to achieve working only with the traditional players" (Kassenova, 20I4, note I72).

The frustrating result of the Teheran Declaration underscores that emerging powers can hardly escape from the restrictions of solely relying on soft power capacities. Recent interpretations underline that unsurmountable world order hierarchy are the main explanation for these limitations (Levaggi \& Yilmaz, 20I8). Challenging these constraints with autonomous stances has been interpreted as costly and counter-productive. In truth, Western powers tend to perceive emerging powers attempt to act autonomously as capricious and unreliable. As already stated, the expanded presence of emerging powers depends on their capacity to be acknowledgement by the international community, particularly the inner circles of world politics (Milani, Pinheiro \& Lima, 20I7). At first, the Brazilian decision do embark with Turkey in talks with Iran responded to incentives transmitted by high-level international actors - including the White House - who chose then to turn down the diplomatic path. Hence, encouragement did not imply a blank check and was withdrawn once Brazil and Turkey decided to pursue a reviewed swap-deal, which complied with certain political requests from the Iranian government.

The Teheran Declaration ought to be considered a valuable chapter in the long story of international negotiations of the Iranian nuclear program. It should as well be acknowledged for its significance, as contestation to Western-led coercive methods to address world security deserves (Metais, 2013). The frustrating result of this initiative did not keep Brazil back from team working with emerging partners - India and South Africa - at the Security Council all through 20II to question liberal interventionist prescriptions enforced in the Arab World.

This text parts from the idea that emerging powers can bring in an innovative approach to deal with international crisis trapped in vicious and escalating tensions. Southern players involvement in peace processes rely on the belief they can offer an element of trust and shared worldviews, which may contribute to the engineering of political settlements and peaceful solutions. Together with other second-tier states, they ambition to alter and fit-in the chessboard controlled by dominant world powers (Goetschel, 20II). Yet, emerging powers are not shield from their own vulnerabilities and weakness and that can damage international performance and make them volatile actors in the international scene (Gardini, 20I6). The Lula government faced

4I Author interview. 
a securitized world in which the North-South divide reinforced with the view that threats were associated to vulnerable realities. Questioning liberal prescriptions arouse irritation and distrust, particularly from the US.

During the second term of the Obama administration (2012-2106), after Security Council sanctions against Iran were enforced, a fresh negotiation process, conducted by the $5^{\mathrm{P}+\mathrm{I}}$, under US leadership, resulted in the Joint Comprehensive Plan of Action (JCPOA) ${ }^{42}$. In mid-20I5, after two years of talks, the deal was announced as an extraordinary deed for world peace ${ }^{43}$. A comparison between the Teheran Declaration and the JCPOA is hardly sustainable for the enormous differences in scope, contents, actors and procedures (Rocha \& Pereira, 20I4). While contrasts are unquestionable, the swapdeal essence of both negotiations is undeniable. This brings up the question of power politics and readiness/ripeness in peace mediation (Gilady \& Russett, 2002) $)^{44}$.

The double-track strategy put forward by the US in 2010 was truly an incompatible two-timing approach. Western powers option for the sanction resolution quickly dissociated from the tripartite negotiations that resulted in the Teheran Declaration. The Western powers advocated for coercive methods to hurt Iran as an unquestionable route and to reach future negotiations, that which implied a specific timing. For Brazil and Turkey, "the ripe moment" already had been achieved in 20I0, once Iran agreed to the terms of the Teheran Declaration. Brazil and Turkey conceived this negotiation as a first step, which would set the sanctions aside and oxygenate Iran relations with the international community. However, what prevailed was a new round of sanc-

42 In April 20I5, Iran and the P5+I agreed on an Iran nuclear deal framework and in July 20I5, they agreed on the plan. Under this agreement, Iran is supposed to eliminate its stockpile of medium-enriched uranium, cut its stockpile of low-enriched uranium by $98 \%$, and reduce by about two-thirds the number of its gas centrifuges for 13 years. According to the agreement, Iran will only enrich uranium up to $3.67 \%$ and the IAEA will monitor and verify Iran's compliance with the agreement. In return, Iran will receive relief from U.S., European Union, and UNSC nuclear-related economic sanctions. See: BBC News (October I3, 20I7). Iran nuclear deal: Key details, from http://www.bbc.com/news/world-middle-east-33521655.

43 See: Gordon, M., \& Sanger, D. (July I4, 20I5). Deal Reached on Iran Nuclear Program; Limits on Fuel Would Lessen With Time. The New York Times, from https://www.nytimes. $\mathrm{com} / 2015 / 07 / 15 /$ world/middleeast/irannuclear-deal-is-reached-after-long-negotiations.html ; Morello, C., \& DeYoung, K. (July I4, 20I5). Historic deal reached with Iran to limit nuclear program. The Washington Post, from https://www.washingtonpost.com/world/historicnuclear-deal-with-iran-expected-to-be-announced/2015/07/14/5f8dddb2-2 gea-Ire5-a 5eacf74396e59ec_story.html?utm_term=.3f429b7935Io.

44 In addressing the relationship between the theories of ripeness and readiness, Cantekin suggests a comprehensive approach which underlines their complementary nature. (Cantekin, 20I6). 
tions particularly harmful for Iranian economy and detrimental to Western powers-Iran relations ${ }^{45}$. Notwithstanding, it took another three years for the Western powers to agree time was ripe to start negotiations with Iran. Ripeness was justified by the political changes in this country and the effects imposed by 2010 sanctions.

Nevertheless, other calculations failed. Nine years have passed and the Iranian nuclear program is still an unsettled matter in world politics. After celebrated worldwide in 2015, the JCPOA became a controversial subject in the 2016 US presidential campaign and a highly politicized matter at the Capitol. Once in power president Trumps' strident disapproval of the deal with Iran led the White House to decide US withdrawal. For European powers and the IAEA, besides representing a source of misunderstanding with Washington, this opens a new chapter of dangerous uncertainty ${ }^{46}$. Simultaneously, growing turmoil in Iran, fed by the costs of sanctions upon the population and reinforced nationalistic responses from the Teheran regime, contributed to re-install a confrontational climate in Iran relations with the international community. US conflictive policy with Iran has now entered a new phase. Besides, and ironically, Brazil has become a close ally of this approach. The victory of Jair Bosonaro in 2018 presidential elections has led to a dramatic change of Brazilian foreign policy, that includes a strong alignment to the US and unprecedented proxy ties with Israel 47

While essentially speculative, the contra-factual argument might be useful in this case. Broken into four sequenced questions, it conjectures: i) Would the acceptance of the Teheran Declaration by $5 \mathrm{P}+\mathrm{I}$ have avoided UNSC resolution I929? ii) Would this acceptance have accelerated negotiations with Iran that decompressed tension and avoided electoral $20 \mathrm{I7}$ politicization in the US? iii) Would then a broader negotiation similar to the 20I5 JCPA have taken place in better timing regarding US domestic politics? iv) And finally, would peace in the Middle East be less out of hand?

45 Resolution I929 sanctions encompassed a framework for high seas and port inspection of suspicious cargo shipments; asset freeze and travel bans for individuals and companies; expanded arms embargo; financial blockage to Iranian banks transactions

46 See: El País (January I2, 20I8). La UE urge a Washington a mantener el pacto nuclear con Irán, from https://elpais.com/internacional/20I8/OI/II/actualidad/I5I5685864_884220. html.

47

https://en.radiofarda.com/a/bolsoaro-brazil-impact-on-iran-influence-in-latinamerica/29707045.html; https://uk.reuters.com/article/uk-venezuela-politics-usa-brazil/us-brazilian-vice-presidents-discuss-venezuela; https://www.theguardian.com/world/20I9/ mar/I8/jair-bolsonaro-us-visit-alliance-trump. 


\section{REFERENCES}

Abdenur, R. (20I0, July 25). Brasil-Irã: como fazer amigos e dar-se mal. Folha de S. Paulo.

Aguirre, M. (2010, June 2). Brazil, Turkey and Iran. A new global balance. Open Democracy, from https://www.opendemocracy.net/author/ mariano-aguirre.

. (2OI3, January 22). BRICS: a new cooperation model? Open democracy, from http://www.opendemocracy.net/mariano-aguirre/brics-new-cooperation-model.

Amar, P. (20I4). The Middle East and Brazil: perspectives on the new global South. Indiana University Press, Bloomington.

Amorim, C. (20I5). Teerã, Ramalá e Doha [Tehran, Ramallah and Doha]. Benvirá, São Paulo.

Bâli, A. (2013). Negotiating non-proliferation: international law and delegation in the Iranian nuclear crisis. UCLA Law Review, vol. 6I, n. 2. pp. 232-324.

Biersteker, T. J., Eckert, S. E., \& Tourinho, M. (Eds.) (2016). Targeted sanctions. Cambridge University Press.

Bonab, R. G. (2009). Turkey's emerging role as a mediator on Iran's nuclear activities. Insight Turkey, II(3), I6I.

Burges, S. (2013). Mistaking Brazil for a middle power. Journal of Iberian and Latin American Research, I9(2), 286-302.

Cantekin, A. (20I6). Ripeness and readiness theories in international conflict resolution. Journal of Mediation \& Applied Conflict Analysis, 3(2), 75-90.

Cooper, A. F., \& Flemes, D. (20I3). Foreign policy strategies of emerging powers in a multipolar world: An introductory review. Third World Quarterly, 34(6), 943-962.

Dauvergne, P., \& Farias, D. B. L. (20I2). The rise of Brazil as a global development power. Third World Quarterly, vol. 33. Issue.5, pp.903-9I7

Dreyfuss, R. (2010). United States Slams Turkey, Brazil over Iran. Washington Report on Middle East Affairs, August, pp. 28-3I.

Ferdinand, P. (20I4). Rising Powers at the UN: An analysis of the voting behaviour of BRICS States in the General Assembly. Third World Quarterly, Vol. 35, Issue 3, pp.376-391.

Fonseca, G. Jr. (20II). Notes on the Evolution of Brazilian Multilateral Policy. Global Governance, vol. I7, pp.375-397. 
Gardini, G. L. (2016). Brazil: What Rise of What Power? Bulletin of Latin American Research, 35(I), 5-I9.

Gilady, L., \& Russett, B. (200I). Peacemaking and Conflict Resolution. In: Carlsnaes, W., Risse, T., \& Simmons, B. A. Handbook of International Relations. Sage, London, pp.392-408.

Goetschel, Laurence. (20II). Neutrals as brokers of peacebuilding ideas? Cooperation and conflict, 46(3), 312-333.

Guimarães, F. S., \& Almeida, M. H. T. (20I7). From Middle Powers to Entrepreneurial Powers in World Politics: Brazil's Successes and Failures in International Crises. Latin American Politics and Society, 59(4), 2646.

Hacipasalioglu, F. (2014). The significance of 2010 Iran-Turkey-Brazil nuclear deal for Turkey and Brazil. Naval Postgraduate School Monterey.

Heller, C. (20I2). Una contribución por un mundo mejor: las presidencias de México en el Consejo de Seguridad de la ONU (2009-20I0). In: Dondisch, Roberto (coord.). México en el Consejo de Seguridad de la ONU La historia tras bambalinas. México: SRE, Editorial Debate.

Hermann, B. (20II). Soberania, não intervenção e não indiferença: reflexões sobre o discurso diplomático brasileiro. Brasília: FUNAG.

Hirst, M. (20I5). Emerging Brazil: The Challenges of Liberal Peace and Global Governance. Global Society, Routledge. vol. 29, issue ${ }^{\circ}$, pp.359-372.

Hirst, M., \& Lima, M. R. S. (2006). Brazil as an intermediate state and regional power. International Affairs, vol.82, issue I, pp.2I-4O (20I5). Re-thinking global and domestic challenges in Brazilian foreign policy. In: Dominguez, J. (Eds). Routledge Handbook of Latin America in the World, New York, pp.I39-I52.

Hirst, M., Lima. M. R. S., \& Pinheiro, L. (2010). A política externa brasileira em tempos de novos horizontes e desafios. Nueva Sociedad Especial em Português, December.

Hurrell, A. (2006). Hegemony, liberalism and global order: what space for would-be great powers? International affairs, 82(I), I-I9. (2008). Lula's Brazil: a rising power, but going where? Current Histo$r y$, vol Io7, issue io6, pp.5I-57. - (2013). Narratives of emergence: Rising powers and the end of the Third World? Revista de Economia Política, 33(2), 203-22I.

Kassenova, T. (20I4). Brazil's Nuclear Kaleidoscope: An Evolving Identity. Carnegie Endowment for International Peace, Washington D.C. 
Lafer, C. (2010, June 20). Diplomacia brasileira, novas variações críticas. $O$ Estado de S. Paulo.

Levaggi, A.G., \& Yilmaz, S. (20I8). The precarious role of emerging powers in a transforming international order: the Brazilian and Turkish initiative for a nuclear deal with Iran. International Politics, pp. I-20.

Malamud, A. (20II). A leader without followers? The growing divergence between the regional and global performance of Brazilian foreign policy. Latin American Politics and Society, 53(3), I24.

Manzur, T. M. P. G. (20I4). A política externa independente (PEI): antecedentes, apogeu e declínio. Lua Nova: Revista de Cultura e Política, (93), I69-199.

Mares, D. R., \& Trinkunas, H. A. (20I6). Aspirational power: Brazil on the long road to global influence. Brookings Institution Press.

Messari, N. (2006). O Brasil e o Mundo Árabe. In: Altemani, H., Lessa, A. C. (Orgs.). Relações internacionais do Brasil: temas e agendas. São Paulo: Saraiva.

Metais, R. (2013). Can emerging powers call the shots? Brazil, Turkey and alternative approaches towards Iran. Conference on EU Q the emerging powers.

Milani, C. R., Pinheiro, L., \& Lima, M. R. S. (20I7). Brazil's foreign policy and the 'graduation dilemma'. International Affairs, 93(3), 585-605.

Obama, B. (2010). National security strategy of the United States (2010). Diane Publishing.

Ozkan, M. (20I0). Turkey-Brazil Involvement in Iranian Nuclear Issue: What Is the Big Deal? Strategic Analysis, 35(I), 26-30.

Parsi, T. (20I0). The Turkey-Brazil-Iran Deal: Can Washinton Take Yes for an Answer. Foreign Policy, May i8. (2013). A single role of the Dice. Yale University Press.

Patti, C. (2010). Brazil and the nuclear issues in the years of the Luiz Inácio Lula da Silva government (2003-2010). Revista brasileira de politica internacional, 53(2), I78-I95.

Pinheiro, P. S. (20I5). Quatro Anos de Guerra na Republica Arabe Siria: sob o Domínio do Medo e o Fracasso da Diplomacia. Cadernos do IPRI n.2, FUNAG, Brasília, pp.9-22.

Richmond, O. (2009, November I9). Liberal Peace Transitions, a rethink is urgent. Open Democracy, from https://www.opendemocracy.net/oliver-p-richmond/liberal-peace-transitions-rethink-is-urgent. 
Richmond, O., \& Tadjbakhs, S. (20II). Conclusion: typologies and modifications proposed by critical approaches. In: Tadjbakhs, S. Rethinking the Liberal Peace, Routledge, London, pp.22I24I.

Ricupero, R. (20I0). À sombra de Charles de Gaulle: uma diplomacia carismática e intransferível. A política externa do governo Luiz Inácio Lula da Silva (2003-20Io). Novos estudos CEBRAP, (87), 35-58. . (20I7). A diplomacia na construção do Brasil: 1750-2016 [Diplomacy in Brazil's construction: I750-20I6]. Versal Editores.

Rocha, A. J. R., \& Pereira, M. S. S. A. (20I4). Iran Talks: Das Palavras aos Atos. A Declaração de Teerã e o Plano de Ação Conjunto de Genebra em Perspectiva. Contexto Internacional, 36(2), 655-682.

Rodrigues, G. (2017, September 6). Brazil's Foreign Policy: a Regressive Path? Center for Latin American and Latino Studies (American University). https://aulablog.net/20I7/o9/o6/brazils-foreign-policy-a-regressive-path/.

Silva, A. L. R., \& Pilla, B. (20I2). O Oriente Médio na política externa brasileira (I947-20II): aproximação, distanciamento e engajamento. Ciências Q Letras, (5I).

Uziel, E. (20I3). O Voto do Brasil e a Condição de Membro Eleito no Conselho de Segurança das Nações Unidas. Política Externa, 2I(I).

Vigevani, T., \& Cepaluni, G. (2009). Brazilian foreign policy in changing times: the quest for autonomy from Sarney to Lula. Lanham, MD: Lexington.

Vizentini, P. G. F. (I994). O nacionalismo desenvolvimentista e a política externa independente (I95I-I964). Revista Brasileira de Política Internacional, July, pp. 24-36.

(I998) A política externa do regime militar brasileiro.UFRGS, Porto Alegre. 


\section{ABSTRACT}

This paper addresses the role of emerging powers and the importance of Southern soft power resources in global peace negotiations. It aims to examine the performance of Brazil as a contributor to peaceful solutions and the de-escalation of international security tension. Brazilian assertive diplomacy during the Lula da Silva government (2003-2010) made special efforts to build bridges in international negotiations to transcend deadlock scenarios. This text will focus specifically on the 20 Io Brazil-Turkey joint initiative - known as the Teheran Declaration - set forward to mitigate the international tensions caused by the Iranian nuclear program. Both countries worked together to persuade Iran to accept a fuel swap deal which could de-rail a new round of United Nations Security Council sanctions against Iran. The failure to change the course of Western-led coercive actions indicates the restraints emerging powers face as peace intermediators in global security. The lack of acknowledgement from Western powers, while effective to reverse the success of the Brazilian-Turkey initiative, also postponed positive outcomes in international negotiations with Iran. This text suggests re-visiting the consequences of this postponement, particularly after the Trump administration has walked away from the 2015 Joint Comprehensive Plan of Action with Iran.

\section{KEYWORDS}

Emerging Powers, Soft Power, Brazil, Teheran Declaration, Iran Nuclear Programme.

Received on April 15, 2019 Approved on April 24, 2019 